\title{
Chronic Subdural Hematoma and Massive Subgaleal Hematoma Following Pediatric Minor Head Trauma
}

\author{
Dhika Alloyna ${ }^{1}$, Ihsan Z Tala \\ ${ }^{1}$ Resident Neurosurgeon at Universitas Sumatera Utara/ Haji Adam Malik General Hospital, Medan \\ ${ }^{2}$ Head of Pediatric Vascular Division, Neurosurgery Departmet, Universitas Sumatera Utara/ Haji Adam \\ Malik General Hospital, Medan
}

\begin{abstract}
Subdural hematomas result from injury to the bridging cortical veins or from extension of intracerebral contusion in the subarachnoid space. Chronic subdural hematomas are usually observed in infants and result from an undiagnosed or conservatively treated acute subdural hematoma. Treatment depend on the extension and localization of the hematoma. Subgaleal hematoma is caused by rupture of emissary veins and located between the periosteum and the scalp galea aponeurotica extending from the orbital ridges to the nuchal ridge.

A 6-year-old boy presented with a fluctuant mass over the scalp following a minor head injury 4 days earlier with history of headache and vomiting. He had undergone craniotomy procedure ten months earlier due to brain abscess drainage, post operative head CT revealed no abnormal radiologic findings and no clotting disorder was found before. A plain CT head revealed a thick isodense subdural collection overlying the left cerebral convexity and presentation of massive circumferensial subgaleal hematoma. Laboratory findings suggest progressive bleeding with low hemoglobin level of $6.8 \mathrm{~g} / \mathrm{dL}$ but normal coagulation panel.
\end{abstract}

The patient was managed surgically with a left-sided craniotomy hematoma evacuation. The previous subgaleal and subdural drains inserted gradually showed less production 3 days after surgery were withdrawn subsequently. As the clinical symptoms resolved, he was discharged with a slight intermitten headache. The patient was loss to follow-up so there were no post operative imaging.

The majority of chronic subdural hematoma which are frequently encountered in neurosurgical practice, ideally treated with surgical drainage. Minor head trauma can lead to chronic subdural hematoma and massive subgaleal hematoma and these patients should be evaluated for underlying coagulopathy.

Keyword: Chronic Subdural Hematoma, Massive Subgaleal Hematoma, Minor Head Trauma

Abstrak. Perdarahan rongga subdural terjadi karena robeknya jembatan vena kortikal atau merupakan lanjutan dari kontusio serebri pada rongga subarakhnoid. Perdarahan subdural kronik yang dijumpai pada anak-anak biasanta tidak terdiagnosis atay merupakan lanjutan perdarahan subdural akut yang diterapi secara konservatif. Terapi berdasarkan perluasan dan lokasi perdarahan. Hematoma subgaleal disebabkan karena ruptur vena emisaria yang berlokasi antara periosteum dan aponeurosis kulit kepala yang membentang dari orbita hingga nuchal.

*Corresponding author at: alloynadhyka@gmail.com 
Anak laki-laki usia 6 tahun dengan keluhan massa berfluktuasi pada kepala didahului dengan trauma kepala ringan 4 hari sebelumnya diikuti dengan nyeri kepala dan muntah. 10 bulan sebelumnya pasien menjalani prosedur kraniotomi drainase abses otak, pemeriksaan CT scan kepala tidak menunjukkan temuan abnormal secara radiologis dan tidak dijumpai adanya gangguan pembekuan darah sebelumnya. CT scan kepala dilakukan non kontras menunjukkan perdarahan subdural tebal isodens di hemisfer serebri kiri dan adanya perdarahan subgaleal masif yang sirkumferensial. Pemeriksaan laboratorium mencetuskan adanya perdarahan progresif pada level hemoglobin $6.8 \mathrm{mg} / \mathrm{dL}$ dengan panel koagulasi normal.

Pasien diterapi dengan pembedahan kraniotomi evakuasi hematom kiri. Selang drainase yang diaplikasikan subgaleal dan subdural menunjukkan penurunan produksi dan pada hari ketiga dilepaskan. Kondisi klinis membaik, dan pasien dipulangkan berobat jalan dengan keluhan nyeri kepala ringan. Pasien ini tidak kembali untuk kontrol sehingga tidak didapatkan pemeriksaan radiologis setelah operasi.

Kasus perdarahan subdural hematoma kronis secara umum sering dijumpai pada praktek bedah saraf, dan idealnya diterapi dengan drainase pembedahan. Cedera kepala ringan dapat menyebabkan perdarahan subdural kronis dan perdarahan subgaleal masif dan pasien-pasien ini sebaiknya di evaluasi untuk menyingkirkan dugaan koagulopati.

Kata Kunci: Perdarahan Subdural Kronis, Perdarahan Subgaleal Masif, Cedera Kepala Ringan

Received [15 Jan 2019] | Revised [1 Feb 2019] | Accepted [20 Feb 2019]

\section{Introduction}

Chronic subdural hematoma $(\mathrm{cSDH})$ is regarded as one of the most common neurosurgical entities. CSDH mostly exerts its impact upon old patients. In as much as ageing is on rise, cSDH becomes a common neurosurgical predicament. From pediatricians' point of view, chronic subdural fluid collection is a group of related conditions called extra cerebral or extra axial fluid collection. Chronic subdural fluid collection can present cSDH or subdural effusion. The term subdural hygroma, subdural hydroma and benign extra cerebral fluid collection are applied very loosely to describe the same entity. This disease is extremely rare in pediatrics and only few cases are reported. The current paper presents a child with minor head trauma history developing cSDH and massive subgaleal hematoma [1].

\section{Case Presentation}

A six-year-old male was admitted to the emergency department presented with fluctuant mass over the scalp following minor head injury four days earlier. Parents also complaints consciousness deterioration with history of headache, nausea and vomiting over the last four days. On neurological examination, his Glasgow coma scale (GCS) score was E3M5V3 (11/15). Pupils were unequal but still reacted to lights. Signs of meningeal irritation was not found. He had undergone craniotomy procedure ten months earlier due to brain abscess drainage, post operative head CT scan revealed no abnormal radiologic findings and no clotting disorder before. A plain head $\mathrm{Ct}$ scan in the emergency room showed a thick isodense subdural collection overlying the left cerebral convexity and presentation of massive circumferencial subgaleal hematoma. Laboratory findings suggest progressive bleeding with low hemoglobin 
level of $6.8 \mathrm{~g} / \mathrm{dL}$, but normal coagulation panel. The patient was managed surgically with a leftsided craniotomy and hematoma evacuation. Subgaleal and subdural drains were inserted during procedure and withdrawn subsequently after showing less production in three days after surgery. As the clinical symptoms resolved, he was discharged with a slight intermitten headache. Follow-up neurological assesment cant be done because the patient was loss-tofollow-up and so there were none post operative imaging.

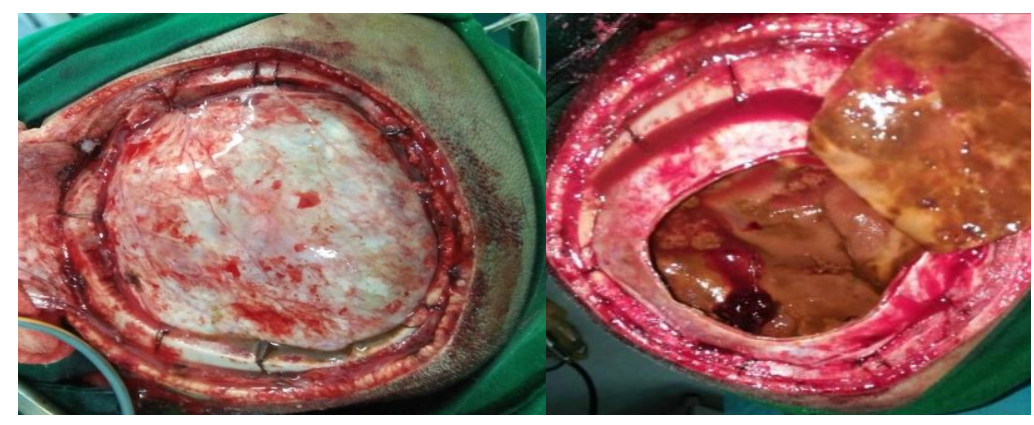

Figure 1 Craniotomy procedure ten-months earlier

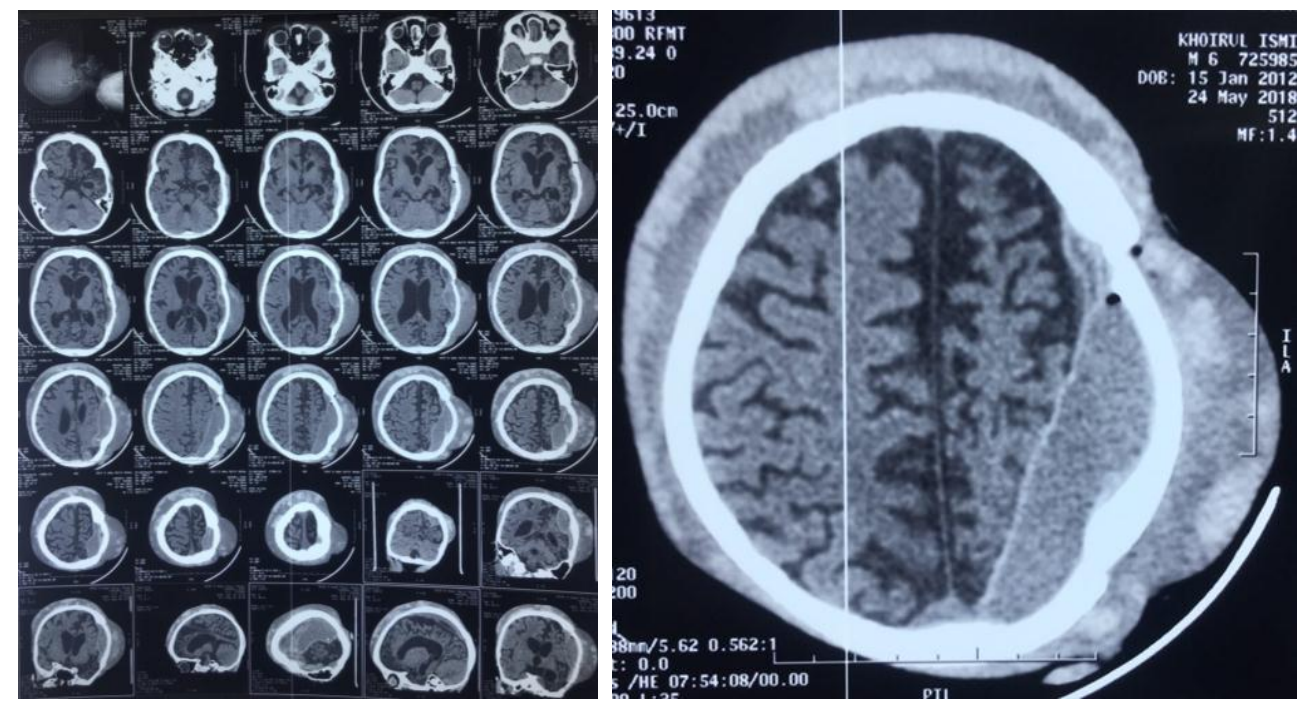

Figure 2 Plain Head CT Scan revealed thick isodense subdural collection and massive circumferencial subgaleal hematoma

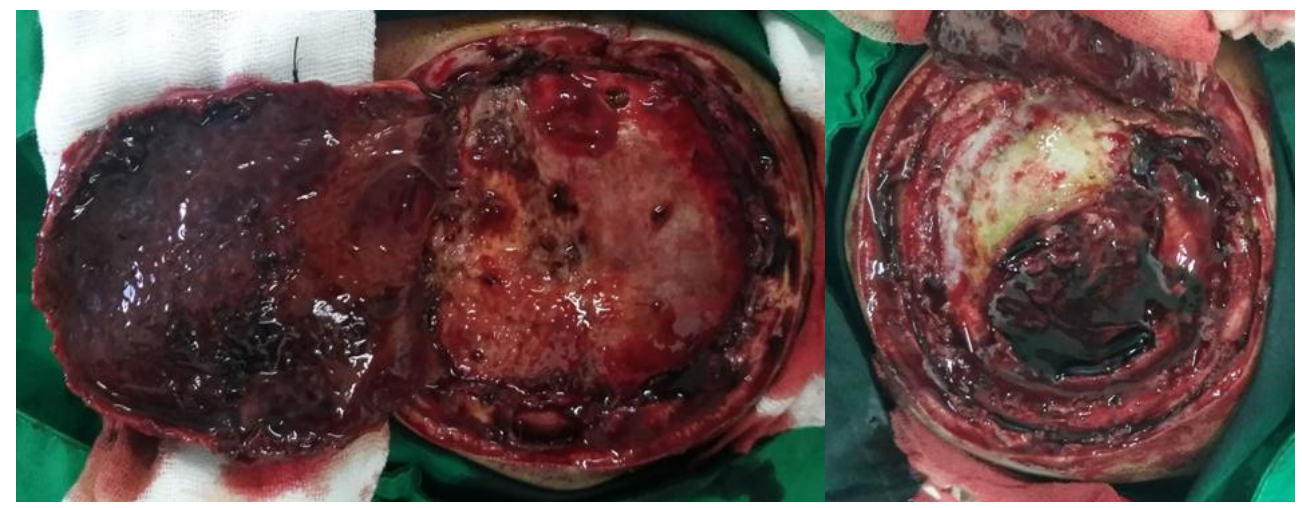

Figure 3 Craniotomy procedure for hematoma evacuation and drainage 


\section{Discussion}

A cSDH is defined as a chronic ( $\geq$ three weeks) intracranial bleeding between the dura mater (adhering to the skull) and the arachnoid mater (enveloping the brain). Two age groups are mostly at risk of developing cSDH, infants and the elderly. Risk factors of cSDH include an age of older than 60 years, male gender, alcoholism, blood dyscrasias, cerebrospinal fluid (CSF) shunts. The patient can present with progressive clinical syndrome characterized by motor deficits, and signs and symptoms of intracranial hypertension [1].

Currently, from the pathophysiologic point of view, chronic subdural hematoma ( $\mathrm{cSDH})$ is considered a separate SDC entity. cSDH denotes a serosanguinous, petroleum-, or crankcaselike fluid collection surrounded and sometimes loculated (divided into compartments) by neomembranes. Neomembranes contain numerous new blood vessels leading to accumulation of contrast agent in neuroimaging studies. The presence of neomembranes represents an important criterion for distinguishing $\mathrm{cSDH}$ and SDH. In contrast to the situation in adults, genuine cSDHs are relatively rare in infants [2].

In the infant brain, SDH is caused by tearing of the bridging veins in the subdural space as a result of rotational and deceleration forces, or by other pathological processes. Spontaneous cSDH in the absence of predisposing conditions is rarely observed in the young subjects. Little is known about SDH in the young population, since in this age group it is not common to observe two of the main predisposing factors for its development including brain atrophy and use of drugs that interfere with hemostasis [1][2].

Subgaleal hematoma is caused by rupture of emissary veins and is typically seen in neonates after vacuum delivery. It is a located between the periosteum and the scalp galea aponeurotica with the subgaleal space extending from the orbital ridges to the nuchal ridge with lateral confinement to the temporal fascia. Furthermore, a subgaleal hematoma is characterized by crossing of the cranial sutures. In older children-as in index patient-it may be seen after minor head trauma or may be of non-traumatic origin. The hematoma often resolves spontaneously or with conservative treatment using a compression bandage (usually within a few weeks). In case of failure of conservative treatment, aspiration or surgery may be mandatory [3] [5].

A craniotomy is the excision of a skull flap over the hematoma to allow surgical drainage or other relief of the collected subdural blood. It is now more commonly used for acute subdural hematomas, or for chronic hematomas that have coagulated into a solid fibrotic or membranous mass and/or calcified. Burr hole craniostomy is the most broadly popular surgical option for primary chronic subdural hematomas in most reporting countries. Drainage was theorized to reduce the recurrence of bleeding from a treated hematoma by the removal of fibrinolytic elements in the accumulated fluid [4]. 
Diagnosis of chronic subdural hematomas in young patients is very rare and a few cases are reported in the literature. Lower incidence of cSDH in children compared to adults caused missing of these patients. The majority of chronic subdural hematoma which are frequently encountered in neurosurgical practice, ideally treated with surgical drainage. Minor head trauma can lead to chronic subdural hematoma and massive subgaleal hematoma and these patients should be evaluated for underlying coagulopathy.

\section{REFERENCES}

[1] M. Emamhadi, S.Y. Chabok, B. Alijani and H. Behzadnia. Chronic Subdural Hematoma in Pediatrics: A Case Report and Literature Review of Rare Cases, Trauma Monthly, TraumaMon.inpress(inpress):e38529, 2016. [Online]. Available: https://www.researchgate.net/publication/309873815 [Accessed: Aug. 17, 2018].

[2] D. Wittschieber, B. Karger, H, Pfeiffer and M.L. Hahnemann. Understanding Subdural Collections in Pediatric Head Trauma, American Journal of Neuroradiology, American Journal of Neuroradiology, 2018. [Online]. Available: https://www.ajnr.org [Accessed: Aug. 17, 2018].

[3] The Efficacy and Safety of Burr-hole Craniotomy Without Continuous Drainage for Chronic Subdural Hematoma and Subdural Hygroma in Children Under 2 Years of age, Journal of Child Nervous Systems, Springer Link, 2016. [Online]. Available: https://www.link.springer.com [Accessed: Aug. 17, 2018].

[4] U.S. Department of Veterans Affairs. Evolving Management of Symptomatic Chronic Subdural Hematoma: Experience of a Single Institution and Review of the Literature, NeurolRes, 2013. Available: https://www.ncbi.nlm.nih.gov [Accessed: Aug. 17, 2018].

[5] S Meyer, L Gortner, H Abdul-Khaliq. Subgaleal Hematoma, The Indian Journal of Pediatrics, 2014. [Online]. Available: https://www.link.springer.com [Accessed: Aug. 17, 2018]. 